\title{
The Work of Redemption: King Lear and The Red Book
}

\begin{abstract}
Matthew A. Fike
Abstract. The Red Book by C. G. Jung remains an unexplored analogy for William Shakespeare's King Lear. Jungian critics of the play have mainly emphasized Lear's extraverted rationality versus his need to foster introversion and love. Jung's visionary experiences suggest an additional pattern: a departure from an initial state of psychological dysfunction, an encounter with unconscious forces, and a return that reflects inner progress. Within this tripartite structure, the two works share many themes and image patterns; but whereas Jung achieves genuine individuation, Lear's progress is more akin to enantiodromia than to the ideal that The Red Book proposes - a balance or unity of opposites in the creation of a new third state of being.
\end{abstract}

Keywords: Jung, Shakespeare, King Lear, The Red Book, individuation, enantiodromia

\section{Introduction}

Johannes Fabricius argues in Shakespeare's Hidden World: A Study of His Unconscious that Shakespeare's plays are about individuation, the process of making the unconscious conscious and moving toward the wholeness of the Self $(9,11)$. Although the study does not mention King Lear, a key statement does apply: "If errors are unconsciously motivated, the single error and its specific nature may provide an illuminating avenue to the unconscious" (13). In Lear's hamartia (the quantification of love in the division of the kingdom), ego mistakes persona for the Self, and the shadow erupts. Although other scholars explore the resulting psycho-dynamics, The Red Book-C. G. Jung's "soul epic" (Rowland 111), which records his descent into the unconscious-has remained an unexplored analogy, largely because it was not published until 2009.

Murray Stein notes the relevance of Homer's Odyssey, Virgil's Aeneid, Dante's Divine Comedy, Goethe's Faust, and the Bible for study of The Red Book ("How to" 28586). However, there is no evidence that Jung ever read King Lear, and Sonu Shamdasani frankly asserts that "[f]igures from Shakespeare's plays do not feature in Jung's pantheon" (C. G. Jung 19). In fact, in The Collected Works Jung refers more frequently to Rider Haggard than to Shakespeare (CW 20, 316 and 614); and The Red Book, though massively allusive, has no internal connection to King Lear. Yet Lear's experience on the heath and Jung's exploration in the depths are so similar in image and insight that perhaps both authors tapped the same wellspring of human experience through the visionary mode of literary composition ( $C W$ 15, par. 139). Although Jung, of course, falls far short of Shakespeare as a literary artist, the works' imbrications suggest that perhaps Harold Bloom errs in his study of the Western canon by overlooking Jung and claiming a lack of "cognitive originality in the whole history of philosophy comparable to Shakespeare's" (10). 
As Mathew V. Spano and others have noted, The Red Book enacts the individuation process, which Stein divides into the three phases in Jung's midlife crisis: destructuring, liminality, and restructuring; or sacrifice of the heroic attitude, initiation into the depths, and inner transformation ("Carl Jung's”). For Nathan Schwartz-Salant, the movement includes narcissism or an "ego-self merger," episodes of chaos/disorder/madness, and individuation through an "ego-self relationship" (14-15). Similarly, Sanford L. Drob understands The Red Book as a journey from conscious ego/persona to a confrontation with the shadow in the unconscious and finally to individuation and the Self $(113,146)$. As a tragedy, however, King Lear dramatizes a truncated version of the individuation process. Lear departs from civilization because of circumstances brought on by various psychological problems, encounters the unconscious on the heath, but does not fully return from the depths in the final scene. Whereas Jung's account hopefully identifies the union of opposites as a means to move successfully toward individuation, Lear's experience, though not entirely hopeless, more nearly approximates enantiodromia, a shift from one quality to its opposite or, in Jung's words, "the emergence of the unconscious opposite in the course of time” ( $C W 6$, par. 709). Although King Lear overcomes the perils of persona and makes notable progress with the shadow and the anima, this essay argues that he ultimately does not achieve the hallmark of individuation in The Red Book-the uniting of opposites into a new third state of being.

\section{Previous Criticism}

The first Jungian criticism of King Lear is Maud Bodkin's Archetypal Patterns in Poetry, first published in 1934, which interprets Lear as both a broken father and "a superhuman figure" who shouts at the elements (16-17). Writing several decades later, Sven Armens, in Archetypes of the Family in Literature, focuses on the main characters' archetypal identifications such as Goneril the Terrible Mother, Cordelia the Kore and the Good Mother, Edmund the egoist, and Edgar the warrior-hero or statesman-hero. Armens's sense that Goneril is “the malformed 'masculine' woman” (175) signals animus possession, though the concept is left unmentioned. The archetypal approach continues in the 1980s with James P. Driscoll's Identity in Shakespearean Drama, which argues that "[t]hough Lear never attains wholeness, throughout King Lear he expands consciousness toward selfknowledge" (149) by moving through stages represented by Yahweh (wrathfulness, injustice), Job (suffering, loss, humility, patience), and Prometheus (awareness of evil, assertion of human good, zeal for justice). Also, Ann E. Imbrie's 1986 article summarizes the main archetypal approaches by mentioning motifs such as "the blind seer, the proud king's abasement ... the suffering servant, the wise fool, the demon-god or dioboia . . . the descent into the underworld, the demon-woman, the wheel . . . the sacrificial victim . . . the tyrant-father, and many others” (69). Lucy Loraine Tubbs, in her unpublished 2010 dissertation, adds to the archetypal approach and reads Lear's descent as an example of Erich Neumann's uroboric state-possession by the unconscious or "the chaotic mingling of consciousness and the unconscious" (33).

Cordelia alone, Driscoll claims, achieves the fourth archetypal stage, Christ (wholeness); however, his assertion that she "symbolizes ideal identity-changeless perfection that needs no improvement, learning, or growth” (142) is questionable in light of her statement of intention upon returning to England.

O dear Father, 
It is thy business that I go about;

Therefore great France

My mourning and importuned tears hath pitied.

No blown ambition doth our arms incite,

But love, dear love, and our aged father's right.

Soon may I hear and see him! (4.4.23-29)

Cordelia may not be in a state of inflation ("blown” or prideful "ambition”), but her love for her father has poisoned her time abroad, and she seeks justice by bringing the French army to English soil, with civil war (analogous to World War I in Jung's experience) being as much an emblem of psychological division as the storm on the heath. Even for Cordelia, perfection of character is out of reach; individuation is a lifelong process, and wholeness can only be approached, never fully achieved.

The standard Jungian interpretation of King Lear, which begins in 1966 with James Kirsch's Shakespeare's Royal Self, emphasizes concepts from depth psychology other than the archetypes. According to Kirsch, Lear begins the play out of touch with the unconscious because he represses affect, projects the anima onto his daughters, and embraces the ego. But the Self creates a situation that enables the "gaining of consciousness" (199); that is, through suffering, individuation arises. When Lear's affects take possession of his consciousness, he descends into madness as Shakespeare understood it: "a condition in which the images and the tempestuous emotions of the unconscious have taken complete possession of him" (269). Along the way, various details signal the dynamics of the unconscious: the word "nothing" is synonymous with the unconscious; the Fool's statements "speak directly to the unconscious in Lear" (213); Nero's fishing "in the lake of darkness" (3.6.6-7) symbolizes Lear's growing introversion or attention to inner processes, including the unconscious; and his restorative sleep in act 4, scene 7, symbolizes the ego's immersion in the unconscious, which helps him toward psychological "[r]ipeness" (5.2.11) or "the greatest possible maturity of the psyche ... the highest possible consciousness" (292). In Kirsch's reading, then, Lear's Christ-like suffering "[u]pon a wheel of fire" (4.7.48) brings psychological benefit in an "inner kingdom" (288). If The Red Book had been available, Kirsch might also have noted Jung's similar image of suffering: "I saw my body lying on sharp needles and a bronze wheel rolling over my breast, crushing it" [437]. Wheels as instruments of torture, however, contrast with The Red Book's mandala images, which signify wholeness and the Self, and with Jung's sense that he is bound to " the wheel of creation," which is “"the revolving wheel of endless happening”" (533).

Alex Aronson's Psyche and Symbol in Shakespeare, published in 1972, adds some important points to the idea that suffering results in individuation. Lear's "darker purpose"-his heretofore "undeclared intention" (Bevington 1172, note on 1.1.36) - is to divide the kingdom in order to prevent "future strife" (1.1.44) and perhaps, as Coppélia Kahn suggests, "to keep his hold on Cordelia at the same time that he is ostensibly giving her away" (39). But Aronson rightly implies that the phrase "darker purpose" heralds movement in the unconscious: Lear transitions from Logos/reason (Goneril and Regan) to Eros/love (Cordelia), from consciousness to affect and the unconscious, or from ego through loss of reason into the unconscious and finally to insight. Significantly, Aronson notes Jung's association of the eye and the sun with consciousness ( $C W 14$, par. 271), which relates to the play's sight pattern and Lear's references to the sun and Apollo. The phrase "ocular proof" from Othello (3.3.376), Aronson suggests, is "Shakespeare's 
metaphor for ego-consciousness attempting to achieve self-knowledge by the use of eyesight only” (27). In other words, King Lear must stop trying to mask psychological problems by focusing on actions in the external world, much as Gloucester, who "stumbled when [he] saw" and could "not see / Because he [did] not feel," learns to see "feelingly" (28; 4.1.19, 67-68; 4.6.149).

According to Aronson, Lear must integrate the anima, which surfaces negatively in his remark, "O, how this mother swells up toward my heart! / Hysterica passio, down, thou climbing sorrow! / Thy element's below" (2.4.55-56). Aronson mentions that the Arden edition traces the Latin phrase to "Passio Hysterica" in the first English book on hysteria, Edward Jordan's Brief Discourse of a Disease Called the Suffocation of the Mother, which was published in 1603, two years before King Lear was written (227). In Janet Adelman's 1992 reading of the passage, the mother (womb) sounds analogous to the anima: "if he was once inside it, it is now inside him, and his suffocating emotions are its sign” (114). Both critics, had they known The Red Book, might have quoted Jung's statement there as a parallel passage: “'Oh most sinister womb! Do you want to suck the life out of me for the sake of the shadow?'” (488). Both passages reflect the dangers of loosing "the anarchic contents of the maternal unconscious" (227). Aronson does link Lear's remark about suffocation by the mother to his later diatribe on female sexuality (227-28; 4.6.107-31). As Kenneth Tucker notes in 2003 in Shakespeare and Jungian Typology, however, Lear eventually moves beyond his aversion for the feminine and toward greater emotion, love, and selfhood (129).

H. R. Coursen's two articles, dated 1980 and 1984, duplicate some points from previous studies but add noteworthy details. In "The Death of Cordelia: A Jungian Approach," Coursen notes, for example, that sexuality run amok in the kingdom is the shadow quality of Lear's absolute control and that he projects his negative anima onto all women. Although the king awakens to anima/intuition, he becomes as extremely childlike at the end as he was childish at the opening. In other words, though Coursen does not use the term, the king's journey is an enantiodromia. Consequently, Lear's rumination on "the mystery of things" (5.2.16) is "yet another dangerous inflation, an obliviousness to the power principle he has exercised so capriciously as king" (10). Coursen's second article, “"Age is Unnecessary': A Jungian Approach to King Lear,” provides a typological analysis of the Lear-Cordelia conflict: Lear's personality is characterized by extraverted thinking and focuses on outer goals, whereas Cordelia, as an introverted feeling type, focuses on the inner life. Lear's long-repressed affect manifests in a compensatory explosion of rage"Lear overcompensates" (90)—which sounds again like enantiodromia. In addition, his tearing at his clothing at 3.4.108 "recreates physically what is happening to him psychologically” (87). Coursen might also have mentioned that Lear's inner turmoil is mirrored in both the microcosm of personal dishevelment ("his little world of man" [3.1.10]) and the macrocosm of the storm, which come together in the phrase "[t]his tempest in my mind” (3.4.12).

\section{Departure}

Stein considers The Red Book to be "a foundational text for Jung's later works in psychology” (“How to” 280); and Lance S. Owens and Stephan A. Hoeller, in their general overview of The Red Book in the Encyclopedia of Psychology and Religion, call its publication "a watershed moment in the understanding of the life and work of C. G Jung" 
(2). Since Jung's visionary account provides the raw material from which he developed much of the psychology that critics have applied to King Lear, it is sensible to consider the parallels between the two texts.

The Red Book begins with two passages from Isaiah that introduce themes relevant to King Lear and establish Christ as a symbol of the journey toward individuation and the Self. In the first passage, "He is despised and rejected of men; a man of sorrows, and acquainted with grief” (117; Isaiah 53.3). Regarding Christ’s pain, Jung subsequently states: "No one can be spared the way of Christ, since this way leads to what is to come. You should all become Christs" (137). As Jung notes elsewhere, "[t]here is no birth of consciousness without pain” ( $C W 17$, par. 331), a formulation similar to Aeschylus's claim in the Agamemnon that "wisdom [or learning] comes through suffering" (line 211). The second passage, from Isaiah 35, suggests that one's suffering may take place away from civilization, and the passage includes various motifs that anticipate the play: wilderness, desert, blindness and sight, fertility, healing, and dragons. Later, the spirit of the depths tells Jung, "The desert is within you"” (123), much as the storm on the heath corresponds to madness in Lear's psyche. According to Isaiah, however, "the habitation of dragons, where each [man] lay, shall be grass with reeds and rushes” (118). Together, the Old Testament passages suggest that a confrontation with the unconscious ("the habitation of dragons") through suffering in a rural area (desert, heath) provides an enhancement to psychic well-being (fertility). In Isaiah, King Lear, and The Red Book, landscape merges with inscape and signifies personal growth.

Whereas the reptilian imagery in Jung's approach to Isaiah seems positive, elsewhere in The Red Book dragon and snake frequently represent repressed content, which will bring harm if ignored. For example, "it is wise to nourish the soul[;] otherwise you will breed dragons and devils in your heart” (130). Even positive qualities may eventually fester in the unconscious: "If one waits long enough, one sees how the Gods all change into serpents and underworld dragons in the end" (287). Later, "Izdubar [Gilgamesh], the mighty, the bull-man" (278), reinforces the threat by perhaps implying that the repressed material in the unconscious may appear in dreams: "'In the night all the serpents and dragons crawl out of their holes and you, unarmed, will inevitably fall victim to them'” (292). The individuation process can be perilous, Jung says, for one may be "devoured by the serpents and dragons lurking on the way to the land of the sun"; but "the divine worm . . . awaits your unsuspecting heel” (297), which adapts God's curse on the serpent in Genesis 3.15 to suggest that affliction may be purposeful. In summary, Shamdasani quotes Jung as stating that "the threat to one's inmost self from dragons and serpents points to the danger of the newly acquired consciousness being swallowed up again by the instinctive soul, the unconscious" (qtd. in Jung, TRB 169, note 140).

The play's reptilian imagery is even more pointedly negative in reflecting violent emotion, ingratitude, and rapier words. After stating that he is fonder of "[t]he barbarous Scythian” than he is of Cordelia, Lear responds to Kent's attempted objection by saying, "Come not between the dragon and his wrath" $(1.1 .116,122)$. In other words, Do not dare to separate the repressed content in the unconscious ("dragon") from its projection ("wrath"). Whereas the dragon's wrath represents his affective response to Cordelia's honesty, he soon realizes her virtues and projects his anger onto Goneril and Regan, stating that having a "thankless child” is "sharper than a serpent's tooth" and that Regan's tongue is "[m]ost serpentlike upon the very heart" (1.4.287-88, 2.4.161). As in The Red Book, 
dragons and snakes suggest unconscious content and instinct, which must be integrated lest Lear be consumed by these forces. So far, though, the reptile images are affective projections onto his daughters rather than a conscious acknowledgement of his own culpability or need for inner work.

There is no doubt in the elder daughters' minds that Lear-now in his eighties (4.7.62)-lacks a little psychologically. Goneril notes "how full of changes his age is" and speculates on "the unruly waywardness that infirm and choleric years bring with them." When Regan suspects that the cause is "the infirmity of his age [senility]," Goneril observes that Lear has not done sufficient inner work: "the imperfections of his long-ingraffed condition" (unruly affects that he has ignored) mean that "he hath ever but slenderly known himself" (is not individuated). As a result, even "[t]he best and soundest of his time hath been but rash" (anger marred even his best years), and his behavior is now characterized by "inconstant starts" (impulsive outbursts) (1.1.292-303; Bevington 1176, note on line 303). In Goneril's "As you are old and reverend, [you] should be wise” and the Fool's "Thou shouldst not have been old till thou hadst been wise" $(1.4 .237,1.5 .43-44)$, it is clear that Lear's age has outstripped his individuation. Instead, he seeks a reversion to childhood, wishing "to set [his] rest / On [Cordelia's] kind nursery," a hope not lost on Goneril who notes that "[o]ld fools are babes again" (1.1.123-24, 1.3.20). When he makes mothers of his elder daughters, he receives not "kind nursery" and pleasant retirement but what the Fool describes as a spanking (1.4.169-71).

As the play opens, one of the roots of Lear's psychological problems is clearly recognizable, as others have noted, in his embrace of rationality over affect and extraversion over introversion. He has focused on his kingly persona and neglected his inner life, much as Jung's initial attitude is “devotion to the ideals of [his] time” (120). In each case, there is an embrace of outwardly focused values such as reason, extrinsic utility, value, pride, and the pomp of kingship/professional success. Moreover, as Kahn states, he has spent a lifetime defending "against admitting feelings and the power of feminine presence into his world” (45). Depth psychology holds, however, that there must be a complementary inner movement so that the content repressed into the shadow is acknowledged and integrated, which is one way to interpret Prospero's remark about Caliban in The Tempest: "This thing of darkness I / Acknowledge mine" (5.1.278-79). Lear must now acknowledge the spirit of the depths, which leads to the unconscious, the archetypes, the feminine, inner worth, intrinsic utility, and basic needs. Jung's statements about his own orientation to the two spirits eerily sum up the king's situation: "I had cultivated my spirit, the spirit of this time in me, but not that spirit of the depths that turns to the things of the soul, the world of the soul” (142). Therefore, it is necessary for Jung to kill Siegfried-“my power, my boldness, my pride” (163)—who represents intellect (Corbett 66); Jung’s “conscious attitudes,” "heroic idealism,” and “ego's will” (MDR 18081); or, as John Beebe and others have noted, perhaps not Freud but Jung's "sonship to Freud" (43; emphasis in the original). Slaying Siegfried is essential in the individuation process, for "[i]f the hero in you is slain, then the sun of the depths rises in you" (Jung, TRB 154).

Lear's attempt to rule the outer world has resulted in inner poverty, a situation summed up nicely by the Cabiri who claim to be " "the master of the lower nature"” (425) and personify "the forces of deep unconscious" (Stein, "Carl Jung's”). "You are a Tom Thumb in the brain," they tell Jung, but "beyond the brain you gain the form of a giant" 
(428). Because his emphasis on the scientific method has caused him to overlook the potential of irrationality and the unconscious, his brain has impoverished him: "Ultimately, where you mistakenly imagine that you are rich, you have actually become poor, and you stand amidst your forms like a beggar" (311). Just so, Lear's worldly prowess has miniscule significance, and he has ignored the inner life that would make him truly great. The words of Jung might well be the words of Lear if he were honest with himself: "I long sought to hold that other spirit [of the depths] away from me" (119). As a result, Lear is in a state of positive inflation, unaware that he has already lost the game. As Jung writes, "He who believes he is really living his ideals, or believes he can live them, suffers from delusions of grandeur [inflation] and behaves like a lunatic in that he stages himself as an ideal [persona]; but the hero has fallen" (273). Lear follows "a blind desire for the hollow things of the world" (129) and searches for himself outside of himself (130). Now the call is to "[turn] away from outer things" in order to "[reach] the place of the soul” (129), for as Jung states in Liber Secundus: "Little good will come to you from outside. What will come to you lies within yourself” (376).

The opening scene displays multiple flaws in Lear's psyche and character that also find parallels in The Red Book. To begin with, Jung's idea that "formation" (persona) inhibits "force" or life force (311-12) informs Lear's role in scene 1. Good persons who have "lost their force completely to their formation," Jung writes, "seek to force others into the service of their formation with unconscious cunning and power"-exactly what Lear intends in the love contest-becoming "bad in their goodness without knowing it, since their longing for satisfaction and strengthening will make them more and more selfish." Jung continues: "But because of this the good ones will ultimately destroy their own work, and all those whom they forced into the service of their own work will become their enemies" —as the elder daughters do in short order- "because they will have alienated them” (312). Also, the following statement in Scrutinies sums up his treatment of his favorite daughter: "You exploit the good faith of others[;] you gloatingly catch them in your snares and speak of your benevolent superiority and the prize that you are for others" (464).

Many additional character flaws and shortcomings are on display in Lear's reaction to the love contest. Regarding his lost temper and dignity, Jung would say to him, "[Y]ou utter a discordant clamor before those whose respect you wanted to exact" (466). In other words, Lear meets Jung's definition of a fool: "A fool is one who exterminates his love for the sake of love. . . . He forces himself upon others; therefore he is cursed into forcing himself upon himself in a cold nothingness" (434). Here is what Lear should have said to his elder daughters: "Do not speak to me about your love. What you call love oozes with self-interest and desirousness. But you speak about it with great words, and the greater your words are, the more pathetic your so-called love is. Never speak to me of your love, but keep your mouth shut. It lies” (465). Instead, his threat to disinherit Cordelia redounds when she becomes Queen of France, he a homeless pauper. Various aspects of Jung's selfindictment in The Red Book apply to Lear as well. Egocentrism: "You begrudge the other the sunshine, since you would like to assign it to those whom you favor because they favor you" (464-65). Pride: "your childish pride, your craving for power, your desire for esteem, your laughable ambition, your thirst for fame without feeling sick. The playacting and pomposity become you badly and you abuse them to the best of your ability” (462). Tyranny: The division of the kingdom shows that "[t]he virtue of giving is the sky-blue 
mantle of the tyrant" (409). And a host of other negative qualities are present: "ambition," "vanity," "self-interest," "general recognition," and personal “advantage” (464). The problem is that Lear attempts to find in the outer world what is available only within, to seek well-being in applause rather than self-esteem. Similarly, Jung criticizes the tendency "to live from the other instead of from himself" and "to find what he [Ammonius, the anchorite] needed in the outer" $(477,262)$. By seeking love in the wrong place and in the wrong way, Lear falls victim to what The Red Book calls "the terrible deceit of life," in which what seems valuable is actually not (236). "Deceitfulness surrounds the giver because his own enterprise is deceitful. He is forced to revoke his gift and to deny his virtue” (476); therefore, Lear disinherits Cordelia and denies his love of her. In short, the king's psyche is stunted because he has embraced the spirit of the time's outer orientation and neglected the spirit of the depths' call to do inner work.

Shakespeare suggests that a key reason for Lear's failure to individuate is a femalesexuality complex. Speaking to Regan, he states, "If thou shouldst not be glad, / I would divorce me from thy mother's tomb, / Sepulch'ring an adultress" (2.4.129-31). That is, If you are not glad to see me, then you are not really my biological daughter. Peter Rudnytsky interprets the remark as "Lear's fantasy" rather than as proof of actual adultery (294), but the statement is part of a strand of language related to whoredom and aberrant sexuality. For example, the Fool comments to him on the weather: "This is a brave night to cool a courtesan” (3.2.79). Goneril criticizes his "hundred knights and squires”-like Siegfried in The Red Book, they represent the heroic attitude-for their debauchery, "[e]picurianism and lust," which make her home "more like a tavern or a brothel / Than a graced palace" (1.4.238-43). In act 3, Lear and Edgar (disguised as Poor Tom) exchange diatribes against female sexuality. Lear, the real madman, condemns his "pelican daughters," an image that suggests feeding at a bloody breast (Bevington 1196, note on 3.4.74); Edgar, the pretend madman, condemns "the act of darkness" and advises Lear, "Keep thy foot out of brothels" (3.4.74, 86, 95); and perhaps Lear projects his own misuse of office onto a "rascal beadle" who whips a whore but "hotly lusts to use her in that kind" (4.6.160-63).

Of course, Edgar's diction anticipates Lear's bitter condemnation of female sexuality in act 4 , scene 6 , where the verse form enacts the dissolution of his psyche. He begins at line 107 by declaring himself "every inch a king," but the iambic pentameter quickly breaks down along with his psyche. The lines vary between four syllables ("Adultery" is its own line for emphasis) and twelve. He mentions both licit and illicit sexuality ("lawful sheets," "copulation," "bastard son”); considers his daughters both human and subhuman ("centaurs" below the waist); and then drops meter completely to describes their nether region as "hell . . . darkness . . . the sulfurous pit, burning, scalding, stench, consumption" - some of the ugliest prose in all of Shakespeare (4.6.107-29). Then, for good measure, he calls Gloucester "blind Cupid,” the symbol of brothels (line 137). The play's sexually charged language suggests that Lear is out of touch with the anima and that he projects his dysfunctional feminine principle onto his elder daughters and women in general, much as the Centaurs attempt to abduct not only the bride Hippodamia but also other Lapith women. Insofar as he considers his good daughter a mother and his wife and evil daughters whores, it appears that Mary, Eve, and Helen are mixed up in his psyche. If Lear and Jung were entirely parallel figures in terms of love, the king would find a way to integrate the negative anima (Goneril and Regan), not just embrace the positive anima 
(Cordelia), as Jung eventually manages to accept the Salome in him and to transform her cruelty and selfish Eros into Agape.

Animality goes hand in hand with aberrant sexuality in The Red Book, as in Jung's noting that "the reek of the human animal streamed over me. Luscious-lewd whores giggled and rustled along the walls" (272). Similarly, Ammonius says, "I drank wine and saw that women were beautiful. I wallowed in pleasure and wholly turned into an animal'” (270). In addition to the nexus of sexuality and animality, the fact that human beings are animals is a major theme in The Red Book. There are references to "the human animal" (231, 240), and animality is in turn associated with irrationality-we are "the irrational animal” (260)—as well as monstrosity. "It seems to me," says Jung, "that I have become a monstrous animal form for which I have exchanged my humanity” (157). Further, Izdubar reminds Jung that human beings are a mixture of higher and lower, rational and irrational, civilized and bestial. In the individuation process, Jung argues, one must acknowledge the depths of one's own animal nature: "He who never lives his animal must treat his brother like an animal. Abase yourself and live your animal so that you will be able to treat your brother correctly" (342). He who does not acknowledge his baser element-the animal nature's "frights and desires" (377)—is bound to treat others monstrously, whereas he who acknowledges his own animality will treat them properly. That is, if a person represses animal baseness and sexuality into the shadow, he will project them onto unsuspecting persons; but if he brings them into the Self, then he will foster the harmony enjoyed by animals of the same species. Jung advises, "Break the Christ in yourself so that you may arrive at yourself and ultimately at your animal which is well-behaved in its herd and unwilling to infringe its laws" (343). Jung devotes a whole paragraph to describing how "[t]he animal does not rebel against its own kind" and "lives fittingly and true to the life of its species” (341). Shamdasani's notes are helpful here. He states that Jung comments on living from one's animal nature as follows: "Yet in nature the animal is a well-behaved citizen . . . you become a peculiarly law-abiding citizen, you go very slowly, and you become very reasonable in your ways, in as much as you can afford it" (qtd. in Jung, TRB 342, note 180). However, as Shamdasani himself states, "In 1939, [Jung] argued that the 'psychological sin' which Christ committed was that 'he did not live the animal side of himself'” (335, note 174).

One may detect some inconsistency in Jung's argument at this point. How can Christ, the symbol of suffering into the Self, be faulted for not acknowledging the body life that he shares with the animals, especially if his forty days in the desert parallel Lear's stormy night on the heath? And did Christ not instruct us on how to live harmoniously with our fellow citizens? Despite these quibbles, the key point is that our animal nature is waiting for us to acknowledge it. Jung writes, "What you excluded from your life, what you renounced and damned, everything that was and could have gone wrong, awaits you behind that wall before which you sit quietly" (340). Negative animality (desires) must be integrated rather than projected so that positive animality (harmony) can be achieved in the social sphere. The two types represent the dynamics of the shadow: "Thus we probably have to accept our evil without love and hate, recognizing that it exists and must have its share in life. In doing so, we can deprive it of the power it has to overwhelm us” (312). The shadow, once befriended, becomes a brother rather than an antagonistic Other, its energy can promote well-being, and now "growth begins" (366). 
The animal imagery in the play-Shakespeare mentions sixty-four different species (Muir 31) and specifically links Goneril to a variety of creatures to emphasize "bestial selfseeking” (Bodkin 15)_demonstrates a mixture of projection and acceptance of animality on Lear's part. In Lear's remarks and the Fool's, the elder daughters are negatively associated with predation, cunning, cruelty, and ingratitude. His "dog-hearted daughters" (4.3.46) are like "she-foxes" that deserve hanging $(3.6 .22,1.4 .316-19)$ or like the cuckoo who bites the head off the mother sparrow that feeds it (1.4.213-14); and Goneril, who has a "wolvish visage" (1.4.307), is worse than a "sea monster" in her ingratitude (1.4.259). Jung's remark sounds critical of Lear: "Man, you have even forgotten that you too are an animal” (391). Failing to live his animal, he projects his repressed animal nature onto his daughters, seeing in them his own unacknowledged animality. Nevertheless, being on the heath does remind the king that he has a physical body. A gentleman's comment that Lear has been out in the storm when bears, lions, and wolves would take shelter (3.1.10-13) suggests that the king is experiencing the same physical vulnerability that the animals do. To the poorly dressed Edgar, he comments that "unaccommodated man is no more but such a poor, bare, forked animal as thou art" (3.4.105-07) and tears off his own clothing as if to share in the bestial state he has just described. Perhaps, as Northrop Frye speculates, these details suggest that Edgar as Poor Tom "provide[s] a solid bottom for Lear's descent" by protecting him from "the world of the furies and fiends" (Northrop 109). A bit later, during the trial scene, Lear's affects "personify as 'little dogs,' and therefore he sees them as 'barking at him'” (Kirsch 251; 3.6.61-62). In The Red Book Jung calls his "thoughts, those unruly hounds" and refers to his ideals as "yapping and squabbling” dogs $(148,275)$, much as one of the female dead calls his virtue "“a wagging dog, a growling dog, a licking dog, a barking dog'” (490). Shakespeare's canine reference echoes the Fool's statement: “Truth's a dog must to kennel. He must be whipped out, when the Lady Brach may stand by the fire and stink" (1.4.109-11). He means: Truth must be forced out of the house and stay in a kennel so that female flattery may have the preferred position. When Lear condemns his elder daughters as dogs, the Fool reminds him that he banished his truthful daughter and favored her dishonest siblings. Commenting on his reign, Lear finally admits to himself that "a dog's obeyed in office" (4.6.158-59). Finally, in prison the king remarks, "He that parts us shall bring a brand from heaven / And fire us hence like foxes" (5.3.2223). Lear exaggerates: He who would part us will need heavenly fire to drive us out of prison, much as fire and smoke drive foxes from their den. In other words, the lines imply "that only death will part them" (Bevington 1213, note on lines 22-23). Maynard Mack suspects an allusion to the heavenly fire that drives Vice offstage in the morality play (59), but there is also a biblical allusion: "So Samson went and caught three hundred foxes, and took torches; and he turned them tail to tail, and put a torch between each pair of tails" (Harper Study Bible, Judg. 15.4). Whatever its source, the imagery suggests that Lear now participates in the fox-like nature that he once projected onto his daughters, though the fantasy of a happy life of confinement with Cordelia does not measure up to the harmonious living and good citizenship that should result from integrating the shadow.

\section{Encounter}

King Lear's descent on the heath to the level of the animals contrasts markedly with Jung's portrait in The Red Book of Philemon's proper retirement. "He was probably only a magician by profession, and he now appears to be a pensioned magician who has retired 
from service. His desirousness and creative drive have expired and he now enjoys his wellearned rest out of sheer incapacity, like every old man who can do nothing else than plant tulips and water his little garden” (397). The reference to gardening echoes two earlier allusions to Candide. The soul says, "'Be content and cultivate your garden with modesty"; and Jung writes: "I return to my small garden that presently blooms, and whose extent I can measure. It shall be well-tended" (375-76). Stein considers the Voltaire allusion to represent minding one's own business and loving the soul (“Carl Jung's"); but these passages also suggest that an elderly person should acknowledge his waning faculties, avoid worldly concerns, and engage in a humble routine that creates beauty. Instead, Lear ironically gives up his office but seeks to retain the trappings of power-his one hundred knights who do not serve him long or well—as he approaches an inner realm where "no father, no mother, no right, no wall and tower, no armor and protective power come to your aid" (315-16; emphasis added). Then he walks out onto the heath where a "tempest" in his mind (3.4.12) will mirror the "pitiless storm" in nature (3.4.29), as for Jung rain represents "the mourning of the dead in me, which precedes burial and rebirth" (164). As in King Lear, so in The Red Book: "eternal chaos ... rushes toward you as if carried by the roaring wings of a storm" (339). In both works, bad weather signals the loosing of the unconscious.

Jung is clear that a descent through suffering into the unconscious is a necessary part of the individuation process. Individuation progresses only if one confronts the "innermost and lowermost," as he says in an earlier draft (qtd. in Jung, TRB 119, note 6). "Your life needs the dark" (360) or "the abyss and awfulness of matter" (313), and The Red Book offers diagnosis and prescription that sum up Lear's situation precisely:

One who wants to rise above himself shall climb down and hoist himself onto himself and lug himself to the place of sacrifice. But what must happen to a man until he realizes that outer visible success, [which] he can grasp with his hands, leads him astray. What suffering must be brought upon humanity, until man gives up satisfying his longing for power over his fellow man and forever wanting others to be the same[?] (390-91)

Christ-like sacrifice and suffering in the psychological depths must displace and compensate for lust for power and desire that others conform to one's wishes. Having left behind the spirit of the time, Lear now allows the spirit of the depths to lead him downward and inward. As Jung puts it, "He [the spirit of the depths] forced me down to the last and simplest things" (120), to "littleness ... [or] the small as a means of healing the immortal in me" (121). For Jung and for Lear, simplicity and littleness refer to the bare essentials of life-fire, food, and shelter. Much as Jung says to Izdubar, "'I'll make a fire to warm us'” (281), "fire and food" are greatly to be desired on the heath (3.4.151). Lear's statement"The art of our necessities is strange, / And can make vile things precious" (3.2.70-71)corresponds to "the valuation of the smallest things" in The Red Book (156). Both Lear and Jung shift from worldly values to appreciation of life's necessities. Elsewhere a similar transition is from cleverness to simplemindedness: "Cleverness conquers the world, but simplemindedness, the soul. So take on the vow of poverty of spirit in order to partake of the soul" (146; emphasis in the original). Once Lear's courtly calculation and Jung's scientific acumen are left behind, the inner work may begin. Lear might then say of the 
heath what Jung says of the desert: "My soul leads me into the desert, into the desert of my own self” (141).

Lear's descent, which is an encounter with poverty and physical extremity, enables him to confront his own inner destitution and to admit that he has not taken proper care of the "[p]oor naked wretches" whom he sees on the heath (3.4.28). He feels compassion for the realm's disadvantaged who endure "the pelting of this pitiless storm" and realizes the necessity of social justice (3.4.28-36). Those people receive a local habitation and a name in Edgar/Poor Tom who is to Lear as a lowly figure is to Jung-a man who is dressed poorly, has scars on his face, and lacks an eye. Jung observes, "He is poor and dirtily clothed, a tramp." As if summing up the situation on the heath, the man says, "'It's damned cold"” (232). The point is that Lear/Jung must embrace in themselves not the king/scientist but the madman/tramp. "What would poverty, nakedness and unpreparedness be without consciousness of weakness and without horror at powerlessness?” Jung asks (378). He wants "to be poor and bare . . . to stand naked before the inexorable" (377), language that echoes Lear's commonality with the "[p]oor naked wretches" he observes and the "poor, bare, forked animal” he supposes Edgar to be (3.4.106). Physical descent is the gateway to the psychological depths. Or, as Regan aptly puts it, for "willful men" like Lear "[t]he injuries that they themselves procure / Must be their schoolmasters" (2.4.304-06).

There is also something more positive: both Lear and Jung have companionship in the depths where growth takes place. Jung writes, "With fear and trembling, looking around yourselves with mistrust, go thus into the depths, but do not do this alone; two or more is greater security since the depths are full of murder" (168). The statement seems to qualify the statement at the end of Liber Secundus: "The touchstone is being alone with oneself. [ף] This is the way" (458). During his visionary period, Jung "carried on a full psychotherapy practice, and did not lose contact with his family life” (Schwartz-Salant 13), much as Lear has the companionship of Kent, Gloucester, the Fool, and Edgar. Lear is down but not alone, and "the mind much sufferance doth o'erskip / When grief hath mates, and bearing fellowship” (3.6.106-07). Descending to the shared poverty of others has psychological benefits, Jung says, for "insofar as you live the life of your fellow beings and descend to their lowliness you also climb into the holy stream of common life, where you are no longer an individual on a high mountain, but a fish among fish, a frog among frogs" (237). Applied to King Lear, the remark points toward the play's religious dimension. Although Bloom reductively holds that King Lear "do[es] not yield to Christianization" (51), Shakespeare includes the Christian paradox that one must fall in order to rise; and, as Roy Battenhouse notes in Shakespeare's Christian Dimension, King Lear is actually a Christian play about a pagan world (446). Abasement is essential to individuation, as Jung suggests in stating, "If you believe that you are the master of your soul, then become her servant" and vice versa (140; emphasis in the original), for when "brought low ... only there do we attain clear knowledge of ourselves" (238). "Therefore he who strives for the highest finds the deepest" (357). As King Lear and The Red Book both emphasize, however, the journey downward and inward does not have to take place in social isolation. Insofar as Lear does shadow work with his male companions, the heath functions much like the "initiation into the 'men's house' and ceremonies of rebirth" that Jung observed in Africa ( $C W 7$, par. 314; 18, par. 363). In order to do anima work with a contra-sexual partner (the "master-piece"), one must first do shadow work with other males (the "apprentice-piece”) (CW 9i, par. 61). It is notable that when Lear asks, "Who is it that 
can tell me who I am?" the Fool replies, "Lear's shadow" (1.4.227-28). A similar exchange occurs in The Red Book. When Jung asks, “'What will remain of me?”” Philemon responds by saying, "'Nothing but your shadow”" (540).

As Kirsch states, "The Fool acts as a typical spiritus familiaris, the objective spokesman for Lear's unconscious" (218); or as Rudnytsky states more simply, the Fool is "Lear's psychotherapist" or "the voice of Lear's unconscious" (298-99). In their remarks, Lear and the Fool engage in the technique that Jung used to generate his inner dialoguesactive imagination - which plays a salutary role. The word "conceit" (4.6.42) in Gloucester's transformation at "Dover" and Lear's actual use of "imagination" at the end of his tirade against female sexuality (4.6.131) suggest that the two fathers are engaging with inner forces. On the imaginal plane, Lear must now do the psychological equivalent of what Philemon has done-taking "the dirty wanderers unsuspectingly into [his] hut," which then becomes "a golden temple” (Jung, TRB 408). The Red Book also affirms the value of such shadow work in Christological terms: "Therefore after his death Christ had to journey to Hell[;] otherwise the ascent to Heaven would have become impossible for him. Christ first had to become his Antichrist, his underworldly brother" (167). In other words, confronting and integrating the shadow are essential to the individuation process, and these processes are essential in turn to Lear's individuation. Because he has neglected not only the "[p]oor naked wretches" in his kingdom but also the corresponding figures within his psyche, ego and persona must now be cast off: the depths demand that he take a careful look at himself on the way to building a psyche focused inward on love instead of outward on power, pomp, and prestige.

Since Lear has become old without becoming wise, he must use his remaining time to make psychological progress toward individuation. The situation is the same with Gloucester who wishes to sit down and "rot even here" (5.2.8), to which Edgar replies, "Men must endure / Their going hence, even as their coming hither; / Ripeness is all" (5.2.9-11). In David Bevington's explication, "Humans shouldn't die before their time, just as fruit doesn't fall until it's ripe” (1213, note on line 11). Or in Frye's words, "man does not own his life, and must wait until it concludes of itself” (Northrop 118). Both explications fall a bit short. Ripeness or full maturity is the goal, but endurance is the essential quality along the way. Ripeness is also an important theme in The Red Book. Early on, the spirit of the time buoys Jung's reason, allowing him to see himself "in the image of a leader with ripe thoughts" (134) but this inflationary orientation immediately yields to a better way: "So: if you are childlike beings now, your God will descend from the height of ripeness to age and death" (135; emphasis in the original). Paradoxically, if one is childlike, one moves inward and abandons what passes in the world as "the height of ripeness"-kingly power, applause-and advances toward "age and death," which promote a kind of ripeness that is compatible with the spirit of the depths. Jung describes the transition as follows: "The time is still not ripe. But through this blood sacrifice, it should ripen. So long as it is possible to murder the brother instead of oneself, the time is not ripe. Frightful things must happen until men grow ripe. But anything else will not ripen humanity" (153-54). The spirit of the time allows one to repress content into the shadow ("murder the brother"); but through sacrifice, frightful occurrences, and suffering, progress can be made toward wholeness (ripeness). In this process, death has a catalytic effect: "Death ripens. One needs death to be able to harvest the fruit . . limitation enables you to 
fulfill your being"; without death, Jung suggests, individuation ("meaning”) would be a lesser imperative (267).

One final reference to ripeness brings us back to King Lear's situation. In reference to "the Gods," Jung writes that "[o]ld and overripe, they have fallen and been buried in an egg" (305), which is an image of enclosed potential. Although Jung "felled the Great One," he "enclosed him lovingly in the maternal egg" (305). When the egg is opened, "Izdubar is standing before me, enormous, transformed, and complete" (306-07; emphasis in the original). What is no longer workable ("old and overripe") can be transformed by the agency of the anima ("maternal egg") into something whole. The egg imagery in King Lear, however, offers a tragic alternative to the hatching of Izdubar.

FOOL. Nuncle, give me an egg and I'll give thee two crowns.”

LEAR. What two crowns shall they be?

FOOL. Why, after I have cut the egg i' the middle and eat up the meat, the two crowns of

the egg. When thou clovest thy crown i' the middle and gav'st away both parts, thou

bor'st thine ass on thy back and o'er the dirt. Thou hadst little wit in thy bald crown

when thou gav'st the golden one away. (1.4.153-61)

The passage echoes Lear's statement to Goneril and Regan: “This coronet part between you" (1.1.139), an impossibility that foreshadows conflict between the Dukes and disaster for the king himself. As "[t]he fool” (Jung's fellow patient in a madhouse) comments on his situation (350), so the Fool in King Lear sums up Lear's hamartia. When the egg is cloven in two, the result is not the hatching of some "God" but consumption of kingship ("the meat") and the division of the kingdom ("gav'st away both parts"), resulting in an inappropriate reversal of power ("bor'st thine ass on thy back"). Yet the Fool is speaking from the point of view of the spirit of the time, not realizing that brokenness in the psyche and in the body politic may yet produce a new and better crown if the maternal soul (Cordelia, anima) is embraced in the depths. In The Red Book, Jung's soul (in the form of a white bird) gives him exactly that, "a golden royal crown" inscribed with the words “"Love never ends"” from 1 Corinthians 13.8 (441)—a crown not of the world but of the soul. A bit later it is "the crown that unites the separated" (454). The egg cloven in two like two crowns represents both Lear's hamartia and the potential for renewal, as Jung suggests in observing that "[o]ut of the egg ... will rise the eagle or phoenix, the liberated soul" (CW 12, par. 306). When the egg of ego/persona cracks open, a person can integrate the unconscious and move toward the proper ripeness of individuation.

\section{Return}

Because King Lear has placed too much emphasis on the outer world and too little on his inner life, he projects repressed content onto others, considering himself "a man / More sinned against than sinning" (3.2.59-60). As Jung knows well, "What we neglect in ourselves blends itself secretly into our actions toward others" (479). He also states that "through constant outer life we forget the self and through this we also become secretly selfish in our best endeavors" (479), as Lear does in the love contest. Then, on the heath, Lear confronts content that he has repressed into the unconscious, doing shadow work with other men and anima work with Cordelia. As Drob sums up Jung's journey in The Red 
Book, "one discovers the depths of one's soul through a courageous encounter with chaos, madness, and the infinite possibilities of sense and nonsense” (88). In other words, both Lear and Jung engage in "the work of redemption," which arises from "an increased need for love” and a "desire to alter our own condition” (Jung, TRB 478-79). Yet Lear's journey is tragic because he does not achieve the ideal — the collapsing of binaries into a new third state-but merely enantiodromia.

Jung's statement perfectly articulates the key process: "We are crucified between the opposites and delivered up to the torture until the 'reconciling third' takes shape" (Letters 375). The idea that suffering transforms binaries into a new and reconciling third state appears in The Red Book- “[a] sacrificial blood binds the poles" (122), for "balance is godly" (150) — but there are other metaphors. Fusion: "one arose from the melting together of the two" (171). Journey: "So the path of my life led me beyond the rejected opposites, united in smooth and-alas!-extremely painful sides of the way which lay before me" (284). Via media: "the God calls me toward the right and the left, his voice calling out to me from both sides. Yet the God wants neither the one nor the other. He wants the middle way. But the middle is the beginning of the long road" (393). Personification: "The opposites embrace each other, see eye to eye, and intermingle” (415). Marriage: "I must unite the two conflicting powers of my soul and keep them together in a true marriage until the end of my life" (405). And procreation: "If you marry the ordered to the chaos you produce the divine child, the supreme meaning beyond meaning and meaninglessness" (139; emphasis in the original).

From various specific binaries that The Red Book articulates arises a new and positive third state of being. Drob summarizes many of the binaries as follows: "word and thing, knowledge and error, sense and nonsense, presence and absence, permanence and change, identity and difference, public and private, freedom and necessity, God and humanity, good and evil, spirit and nature, and mind and matter” (46). He sees Jung's purpose in The Red Book as "reclaim[ing] the value of hitherto debased terms of a series of polarities: madness/sanity, evil/good, chaos/order, doubt/certainty, empty/full, etc.” (148). It is particularly important to reconcile the shadow and the anima in the relationship with Salome: "he must learn to love the shadow and anima aspects of himself"; "[b]y loving Salome, Jung in effect accepts his shadow and anima, forges a new self, is identified with Christ, and ushers in the new God." It is the transcendent function that "transcends and unifies opposing tendencies and attitudes," that is, consciousness and the unconscious (Drob 54, 62-63; emphasis in the original). In Daryl Sharp's definition, the transcendent function is "[a] psychic function that arises from the tension between consciousness and the unconscious and supports their union" (135).

In addition, Jung notes that "virtues and vices are brothers" (TRB 266), just as they are literal brothers, Edgar and Edmund, in King Lear. And there are further binaries relevant to the play. "One cannot live with forethinking alone, or with pleasure alone. You need both" (181). As before, "[i]f forethinking [reason, understanding] and pleasure [feeling, love] unite in me, a third state arises from them, the divine son, who is the supreme meaning, the symbol, the passing over into a new creation” (189). Similarly, as with the Red One and Ammonius, Jung says elsewhere that "[s] exuality and spirituality are pairs of opposites that need each other” in order to produce a whole (qtd. in TRB 528, note 112). A person must not reject lust (the Red One) in favor of spirituality (Ammonius) but must instead achieve a synthesis of both, as those two characters do when they interact in chapter 
7 of Liber Secundus. The following observation illuminates the sexual dynamics of Shakespeare's play: “"The sexuality of man goes toward the earthly [carnality, Edmund, the elder sisters], [but] the sexuality of woman goes toward the spiritual [love, Cordelia]. Man and woman become devils to each other if they do not distinguish their sexuality"” (529). Body and spirit must commingle in the interest of living one's animal. Sense and nonsense - another major opposition that must experience a "melting together . . . which produces the supreme meaning [third state]" (120)—are multivalent. The terms suggest not only meaning versus absurdity or a commonsense scientific outlook versus illogic but also the empirical perception of the outer world via the five senses versus nonsensory perception of what lies within, literally sense versus non-sense, consciousness versus the unconscious. To combine these ways of seeing is meaningful, says Jung, because "[d]epths and surface should mix so that new life can develop" (152), especially via shadow work: "If I accept the lowest in me, I lower a seed into the ground of Hell. The seed is invisibly small, but the tree of my life grows from it and conjoins the Below and the Above” (356).

A couple of binaries in King Lear relate directly to The Red Book, but there are many others - the play is built on binaries. Jung says to Elijah that "whoever possesses wisdom is not greedy for power'” (439). As wisdom and folly unite in the Fool's advice to Lear, wisdom and power unite in the survival of Edgar and Albany at the end of the play, though, as James Shapiro points out, "the widowed and childless Albany offers little prospect for the renewal of the kingdom” (303). For Lear, however, wisdom and power remain in effect a binary-he is restored to his former power at 5.3.304-06 only to die a dozen lines later. Similarly, in the third sermon to the dead, Jung mentions another binary that obtains in King Lear: "Everything that you request from the Sun God produces a deed from the devil'” (521), which nicely glosses Lear's "Now, by Apollo_-" (1.1.161). The unconscious compensates: by overemphasizing what Apollo represents-Logos and male power in the external world-Jung and Lear both move toward wholeness via a confrontation with Eros and the anima in the inner world. The contrast resembles the juxtaposition of Jung's No. 1 and No. 2 personalities (MDR, chapter 3, esp. 87-88), which encompass various binaries common to King Lear and The Red Book. These include the spirit of the time/depths, civilization/heath, Tom Thumb/giant, sense/nonsense (or nonsense), persona/shadow, ego/Self, extraversion/introversion, repression/compensation, and projection/individuation. Other binaries specific to the play are pride/humility, tyranny/social justice, applause/self-esteem, pomp/basic needs, and day/night.

As Drob points out, "Jung understood the development of the Self, of the "new man,' in terms of a coincidence of opposites which re-incorporates the rejected pole of a number of value pairs" into a "coincidentia oppositorum, the co-existence, blending, and interdependence of opposites" (44-45). Similarly, binaries are also key to understanding the difference between tragedy and comedy. A comedy like A Midsummer Night's Dream begins with a departure from an initial setting where the binaries' first terms constitute a problem, moves to an encounter in which the binaries' second terms are engaged, and achieves a return that enables the creation of a new third state in which opposites are reconciled. For example, as Frye affirms, "[i]n comedy the erotic and social affinities of the hero are combined and unified in the final scene” (Anatomy 218). By overcoming problems, characters in a comedy bring renewal and reconciliation out of chaos and suffering. Tragedy shears away that reunifying third phase so that a character like Lear shifts from one extreme to another-enantiodromia-rather than fully synthesizing 
opposite parts of his psyche. He ends up not at a wedding celebration like the characters in Dream but in prison where, instead of merging reason and affect, he abandons the one and embraces the other. As Lear approaches the end of his life, suffering abides, senility qualifies learning and wisdom, and loss outweighs reconciliation.

Of course, being imprisoned can be meaningful, as Jung suggests at two points in The Red Book. He learns that the one-eyed man is "a former convict" who lost an eye in a brawl over a woman who was pregnant with the other man's bastard; the half-sighted man says that "“it was beautiful in prison,"” and Jung opines to the reader how hitting bottom makes one cognizant of "the whole height of reality" (235). After all, at rock bottom, there is nowhere to go but up. Later Jung speaks to a woman who also lauds the positive potential of imprisonment: "'there I have peace and can collect myself. . . . Doors of iron, walls of stone, cold darkness and the rations of penance - that is the bliss of redemption'” (499). Consequently, it is possible that Lear's intention to "take upon 's the mystery of things, / As if we were God's spies" (5.3.16-17) reflects "the work of redemption" (478) if "mystery" refers to the positive second half of the binary. In The Red Book, the spirit of the depths tells Jung that the world's mysteries dwell in him (121); he claims to be ignorant of the "mystery" of his soul, which appears in his dreams "as a child and as a maiden," that is, as a Cordelia figure (131); "mystery" relates to inner growth (135; emphasis in the original); it is a general term for interiority (202); the spirit of the depths "leads mankind through the river of blood to the mystery," meaning that suffering leads to individuation (205); and "mysteries" are "the otherworldly powers of the spirit and desire" (439). In short, "mystery" characterizes the inner world, the No. 2 personality, and the second term in various binaries. By facilitating the apprehension of mystery, time spent in prison may not be all bad.

But does Lear, as Kirsch affirms, move from "pagan doctrines through suffering and spiritual regeneration to an inner experience of God" (311; emphasis added)? The pagan doctrines are sufficiently evident in Lear's earlier invocation of Hecate, Jupiter, and Apollo; but the claim of "an inner experience of God"-in Jung, "the experience of the numinosum [is] wholly immanent," as Lionel Corbett reminds us (69)—may be based on a misreading of Lear's use of "the mystery of things" and "God's spies” in his statement about imprisonment with Cordelia.

No, no, no, no! Come, let's away to prison.

We two alone will sing like birds i' the cage:

When thou dost ask me blessing, I'll kneel down

And ask of thee forgiveness. So we'll live, And pray, and sing, and tell old tales, and laugh

At gilded butterflies, and hear poor rogues

Talk of court news; and we'll talk with them too-

Who loses and who wins; who's in, who's out-

And take upon 's the mystery of things,

As if we were God's spies; and we'll wear out, In a wall'd prison, packs and sects of great ones,

That ebb and flow by the moon. (5.3.8-19)

In keeping with the strand of religious language ("blessing," "forgiveness," "pray”), which suggests that Lear has developed a more peaceful, positive outlook as a result of his suffering on the heath, perhaps the statement "And take upon 's the mystery of things, / As 
if we were God's spies” signifies something esoteric or spiritual. If, as Mack states, Lear and Cordelia "will be in the world but not of it" (113), there may even be a hint of a new third state. Perhaps, as Bevington suggests, “God's spies” are simply "detached observers surveying the deeds of humanity from an eternal vantage point” (1213, note on line 17). But given what frames the key statement- "court news" as well as "packs and sects of great ones"-it seems likely that the primary meaning of "the mystery of things" and "God's spies" is horizontal and human rather than vertical and spiritual. Interest in current events also appears to qualify Kirsch's sense that Lear ends up detached from reality in a state of total introversion, as well as Aronson's claim that Lear's imagined paradise-inprison involves "a permanent retreat from the reality of human society" (188).

Given the prison passage's ambiguity, it is likely that Lear has achieved enantiodromia rather than a new third state. Nearing the end of his journey, he still expresses interest in the outer world of the court, which reflects the first half of the binary, but there may also be some engagement with the second half in light of The Red Book's relation of "mystery" to inner life and individuation. In a positive reading, his new outlook on life reflects not only anticipation of the pleasure of discussion with his favorite daughter but also some degree of synthesis of inner and outer. Perhaps discoursing on "the mystery of things" refers to the archetypes that underlie human behavior; to what Coursen, referring to Kent, calls "an ability to sense the interior content of the exterior world" ("The Death of Cordelia" 5); or to Jung's idea "that the spirit of the depths in [him] was at the same time the ruler of the depths of world affairs" (123). In a more skeptical reading, however, Lear has swung from rejecting Cordelia to embracing her. Now he projects his potential for happiness onto her and makes her responsible for it, much as he expects his daughters to flatter him with their expressions of love in scene 1. In light of Jung's statements in The Red Book, the skeptical interpretation seems to carry more weight. Individuation, Jung asserts, involves "unit[ing] with the serpent of the beyond" and "accept[ing] everything beyond into myself" (430) or what Shamdasani calls "a synthesis of the individual [psyche] with the collective psyche" ("Liber Novus" 51). A swing to the opposite such as Lear achieves is supposed to be a step in this process, not a final destination. As Shamdasani states, "By what [Jung] termed the law of enantiodromia, or the reversal into the opposite, the other function entered in. . . . The development of the contrary function led to individuation" ("Liber Novus” 56; emphasis added). To say that Lear has made no progress would be inaccurate: he has grown, and both inner and outer seem present in his "mystery" speech; however, his new outlook reverses his opening mindset but does not constitute a new third state that arises from proper integration of the many binaries that structure the play. Neither Lear's experience of opposites nor his work with shadow and anima has transformed him into a senex like the prophet Elijah in The Red Book. Although certainly a "child-changèd father," he remains, by his own admission, old and foolish (4.7.17, 61, 90).

\section{Conclusion}

In The Red Book, the "Pleroma" is another way that Jung expresses the uniting of opposites. He calls it a state "in which all opposites are canceled out and unified" (517), "a state of fullness where the pairs of opposites . . . are together” (qtd. on 509, note 82). Since opposites are united in the Pleroma and the unconscious, "the pursuit of one quality will necessarily bring on its opposite” (Drob 267). For example, Pleroma encompasses both 
nothingness and fullness, which apparently coexist there without contradiction. Contrary to Lear's prediction that "[n]othing will come of nothing” (1.1.90), something does come of nothing: the king's debasement on the heath and in prison may not lead to complete spiritual fullness, but he makes some progress on the journey toward individuation, though he does not achieve the proper balance of the reconciling third state. Pleroma's identification with the unus mundus, the one world or unitary world, a field of energy that unites matter, psyche, and spirit, also has a parallel in the play. Lear's experience spans all three dimensions: a descent into nature and the unconscious, followed by a physical death and a transition to the spirit world. Despite the final scene's apocalyptic nihilism, there are indications of the afterlife in Lear's apparent ability to see Cordelia's spirit and Kent's conviction to follow his "master" on a "journey" into the afterlife (5.3.317, 327-28). A. C. Bradley claims too optimistically that Lear dies in a state of "unbearable joy" (291; emphasis in the original), but there is a sense in Edgar's closing remark that lessons have been learned: "The weight of this sad time we must obey; / Speak what we feel, not what we ought to say" (5.3.329-30), which is certainly "a vindication of the conduct of Cordelia and Kent in the opening scene” (Frye, Northrop 115). Since their blunt honesty is endorsed and expedient lies are condemned, the play's final speech reverses Lear's hamartia. As Fabricius proposes, error opens the pathway to individuation. One must respond or suffer the consequences of repression, for as Coursen rightly states, "Man may ignore his unconscious, but it will not ignore him" ("The Death of Cordelia” 6). These remarks are in sync with the moral of The Red Book: "The spirit of the depths demands: "The [inner] life that you could still live, you should live”' (134). As with King Lear's tragic outcome, sometimes that greater life exacts a high price.

\section{Contributor}

Matthew A. Fike holds a PhD from the University of Michigan and is a professor of English at Winthrop University in Rock Hill, SC. He is the author of A Jungian Study of Shakespeare: The Visionary Mode and several other Jungian literary monographs.

\section{Works Cited}

Adelman, Janet. Suffocating Mothers: Fantasies of Maternal Origin in Shakespeare's Plays, Hamlet to The Tempest. Routledge, 1992.

Aeschylus. Agamemnon. Translated by Ian Johnson, 1 Oct. 2002, johnstoi.web.viu.ca//aeschylus/aeschylus_agamemnon.htm. Accessed 7 July 2020.

Armens, Sven. Archetypes of the Family in Literature. U of Washington P, 1966.

Aronson, Alex. Psyche \& Symbol in Shakespeare. Indiana UP, 1972.

Battenhouse, Roy, editor. Shakespeare's Christian Dimension: An Anthology of Commentary. Indiana UP, 1994.

Beebe, John. "The Red Book as a Work of Conscience: Notes from a Seminar Given for the 35th Annual Jungian Conference, C. G. Jung Club of Orange County, April 10, 2010.” Quadrant, vol. 40, no. 2, 2010, pp. 41-58.

Bevington, David, editor. The Complete Works of Shakespeare. 4th ed., HarperCollins Publishers, 1992. 
Bloom, Harold. The Western Canon: The Books and School of the Ages. Harcourt Brace, 1994.

Bodkin, Maud. Archetypal Patterns in Poetry: Psychological Studies of Imagination. 1934. Oxford UP, 1971.

Bradley, A. C. Shakespearean Tragedy: Lectures on Hamlet, Othello, King Lear, Macbeth. 2nd ed., Macmillan, 1926.

Corbett, Lionel. "Jung's The Red Book Dialogues with the Soul: Herald of a new Religion?” Jung Journal: Culture \& Psyche, vol. 5, no. 3, Summer 2011, pp. 6377. JSTOR, www-jstororg.winthropuniversity.idm.oclc.org/stable/10.1525/jung.2011.5.3.63. Accessed 22 June 2020.

Coursen, H. R. “'Age is Unnecessary’: A Jungian Approach to King Lear.” The Upstart Crow: A Shakespeare Journal, vol. 5, Fall 1984, pp. 75-92. (Rpt. in The Compensatory Psyche: A Jungian Approach to Shakespeare. University Press of America, 1986, pp. 129-50.)

_ . "The Death of Cordelia: A Jungian Approach.” The Hebrew University Studies in Literature, vol. 8, 1980, pp. 1-12.

Driscoll, James P. Identity in Shakespearean Drama. Buchnell UP, 1983.

Drob, Sanford L. Reading The Red Book: An Interpretive Guide to C.G. Jung's Liber Novus. Spring Journal Books, 2012.

Fabricius, Johannes. Shakespeare's Hidden World: A Study of His Unconscious. Munksgaard, 1989.

Frye, Northrop. Anatomy of Criticism: Four Essays. Atheneum, 1968. . Northrop Frye on Shakespeare. Yale UP, 1986.

Harper Study Bible. General editor, Harold Lindsell, Zondervan, 1982.

Imbrie, Ann E. “An Archetypal Approach.” Approaches to Teaching Shakespeare's King Lear, edited by Robert H. Ray, The Modern Language Association of America, 1986, pp. 69-74.

Jung, C. G. The Collected Works of C. G. Jung. Edited by Sir Herbert Read et al., translated by R. F. C. Hull, 2nd ed., Princeton UP, 1953-91. 20 vols. Bollingen Series 20.

—. Letters. Edited by Gerhard Adler and Aniela Jaffé, translated by R. F. C. Hull, vol. 1, Princeton UP, 1973. Bollingen Series 95.

—. Memories, Dreams, Reflections. Edited by Aniela Jaffé, translated by Richard and Clara Winston, rev. ed., Vintage Books, 1989.

- The Red Book: Liber Novus: A Reader's Edition. Edited by Sonu Shamdasani, translated by Mark Kyburz, John Peck, and Sonu Shamdasani, W. W. Norton, 2009. Philemon Series.

Kahn, Coppélia. "The Absent Mother in King Lear.” Rewriting the Renaissance: The Discourses of Sexual Difference in Early Modern Europe, edited by Margaret W. Ferguson et al., The U of Chicago P, 1986, pp. 33-49.

Kirsch, James. Shakespeare’s Royal Self. G. P. Putnam’s Sons, 1966. 
Mack, Maynard. King Lear in Our Time. U of California P, 1965.

Muir, Kenneth. Shakespeare: The Great Tragedies. Longmans, Green, 1963.

Owens, Lance S., and Stephan A. Hoeller. "Carl Gustav Jung and The Red Book: Liber Novus.” Encyclopedia of Psychology and Religion, 2nd ed. Springer Reference, 2014, pp. 1-8, www.academia.edu/6922901/C._G._Jung_and_the_Red_Book_Encyclopedia_Art icle_2014_. Accessed 11 July 2020.

Rowland, Susan. Jungian Literary Criticism: The Essential Guide. Routledge, 2019.

Rudnytsky, Peter. “'The Dark and Vicious Place': The Dread of the Vagina in King Lear.” Modern Philology: Critical and Historical Studies in Literature, Medieval Through Contemporary, vol. 96, no. 3, Feb. 1999 pp. 291-311.

Schwartz-Salant, Nathan. "The Mark of One Who Has Seen Chaos: A Review of C. G. Jung's Red Book.” Quadrant, vol. 40, no. 2, Summer 2010, pp. 11-38.

Shamdasani, Sonu. C. G. Jung: A Biography in Books. W. W. Norton, 2012.

—. “Liber Novus: The ‘Red Book’ of C. G. Jung.” Jung, The Red Book, pp. 1-95.

Shakespeare, William. King Lear. Bevington, pp. 1172-1218.

. Othello. Bevington, pp. 1122-66.

- The Tempest. Bevington, pp. 1529-58.

Shapiro, James. The Year of Lear: Shakespeare in 1606. Simon \& Schuster, 2015.

Sharp, Daryl. Jung Lexicon: A Primer of Terms \& Concepts. Inner City Books, 1991.

Spano, Mathew V. "Modern(-ist) Man in Search of a Soul: Jung’s Red Book as Modernist Visionary Literature.” The Jung Page: Reflections on Psychology, Culture and Life, 27 Oct. 2013, www.cgjungpage.org/learn/article/literature/934-modern-istman-in-search-of-a-soul-jungs-red-book-as-modernist-visionary-literature. Accessed 9 July 2020.

Stein, Murray. “Carl Jung’s Red Book.” Asheville Jung Center, 22 Jan. 2010. Video. . "How to Read The Red Book and Why." Journal of Analytical Psychology, vol. 57, no. 3, June 2012, pp. 280-98. EBSOhost, onlinelibrary-wileycom.winthropuniversity.idm. oclc.org/doi/epdf/10.1111/j.14685922.2012.01972.x.

Tubbs, Lucy Loraine. "Responses to the Jungian Archetypal Feminine in King Lear, Hamlet, Othello, and Romeo and Juliet.” Diss. Baylor U, 2010.

Tucker, Kenneth. Shakespeare and Jungian Typology: A Reading of the Plays. McFarland, 2003. 